Article

\title{
Entomotoxic Activity of Prasiola crispa (Antarctic Algae) in Nauphoeta cinerea Cockroaches: Identification of Main Steroidal Compounds
}

\author{
Graziela Holken Lorensi ${ }^{1}$, Raquel Soares Oliveira ${ }^{1}$, Allan P. Leal ${ }^{7}$, , Ana Paula Zanatta ${ }^{1}$, \\ Carlos Gabriel Moreira de Almeida ${ }^{2}$, Yuri Correia Barreto ${ }^{1}$, Maria Eduarda Rosa ${ }^{1}$, \\ Patrícia de Brum Vieira ${ }^{1,4}$, Carlos José Brito Ramos ${ }^{6} \mathbb{D}$, Filipe de Carvalho Victoria ${ }^{3}$ (D), \\ Antônio Batista Pereira ${ }^{3}$, Valéria LaneuvilleTeixeira ${ }^{5,6}$ (D) and Cháriston André Dal Belo ${ }^{1,7, *(D)}$ \\ 1 Laboratório de Neurobiologia e Toxinologia (LANETOX),Universidade Federal do Pampa, Campus São \\ Gabriel, São Gabriel, RS 97307-020, Brazil; grazielahl@gmail.com (G.H.L.); \\ raquelsoaresoliveira@yahoo.com.br (R.S.O.); anapaulabiotech@gmail.com (A.P.Z.); \\ barreto78@outlook.com (Y.C.B.); rosaedumaria@gmail.com (M.E.R.); patriciasbrum@yahoo.com.br (P.d.B.V.) \\ 2 Instituto do Cérebro (INSCER), Pontifícia Universidade Católica do Rio Grande do Sul, Porto Alegre, \\ RS 90610-000, Brazil; carlos.gabriel@acad.pucrs.br \\ 3 Núcleo de Estudos da Vegetação Antártica (NEVA), Universidade Federal do Pampa, Campus São Gabriel, \\ São Gabriel, Rio Grande do Sul 97307-020, Brazil; filipevictoria@unipampa.edu.br (F.d.C.V.); \\ antoniopereira@unipampa.edu.br (A.B.P.) \\ 4 Grupo de Pesquisa em Estresse Oxidativo e Sinalização Celular, Universidade Federal do Pampa, Campus \\ São Gabriel, São Gabriel, RS 97307-020, Brazil \\ 5 Programa de Pós-Graduação em Ciências e Biotecnologia, Instituto de Biologia, Universidade Federal \\ Fluminense, Centro, Niterói, RJ 24020-141, Brazil; valerialaneuville@gmail.com \\ 6 Programa de Pós-Graduação em Biodiversidade Neotropical, Universidade Federal do Estado do Rio de \\ Janeiro, Rio de Janeiro, RJ 22290-255, Brazil; cjbramos@gmail.com \\ 7 Programa de Pós-Graduação em Bioquímica Toxicológica, PPGBtox, Universidade Federal de Santa Maria, \\ UFSM, Bairro Camobi, Santa Maria, RS 9705-900, Brazil; allan-leal@hotmail.com \\ * Correspondence: charistonbelo@unipampa.edu.br
}

Received: 31 July 2019; Accepted: 11 September 2019; Published: 10 October 2019

check for updates

\begin{abstract}
Prasiola crispa is a macroscopic green algae found in abundance in Antarctica ice free areas. Prasiola crispan-hexaneextract (HPC) induced insecticidal activity in Nauphoeta cinerea cockroaches after $24 \mathrm{~h}$ of exposure. The chemical analysis of HPC revealed the presence of the followingphytosterols: $\beta$-sitosterol, campesterol and stigmasterol. The incubation of cockroach semi-isolated heart preparations with HPC caused a significant negative chronotropic activity in the heartbeats. HPC affected the insect neuromuscular function by inducing a complete inhibition of the cockroach leg-muscle twitch tension. When the isolated phytosterols were injected at in vivo cockroach neuromuscular preparations, there was a progressive inhibition of muscle twitches on the following order of potency: $\beta$-sitosterol > campesterol $>$ stigmasterol. HPC also provoked significant behavioral alterations, characterized by the increase or decrease of cockroach grooming activity, depending on the dose assayed. Altogether, the results presented here corroborate the insecticide potential of Prasiola crispa Antarctic algae. They also revealed the presence of phytosterols and the involvement of these steroidal compounds in the entomotoxic activity of the algae, potentially by modulating octopaminergic-cholinergic pathways. Further phytochemical-combined bioguided analysis of the HPC will unveil novel bioactive compounds that might be an accessory to the insecticide activity of the algae.
\end{abstract}

Keywords: Antarctic algae; biological activity; insecticide; marine steroids; marine natural products 


\section{Introduction}

Antarctica is the fifth largest continent on earth; its territory covers about $10 \%$ of our planet land surface with 14 million square kilometers [1]. Antarctica is known for its extreme climate conditions, being the coldest, driest and windiest continent on the planet [2]. Besides its permanent low temperatures, the Antarctica's rate of precipitation is comparable to the world's driest deserts [3]. Life on the Antarctic continent is basically composed of algae, fungi, bacteria (actino-mycetes) and some plant species [1,3]. Thus, Antarctica's extreme conditions provide a perfect environment for the living organisms to synthetize new chemicals with a range of different biological properties, including entomotoxic molecules [4]. Among the vegetal organisms well adapted to the Antarctica's stressful conditions, there are few algae species, including green algae from the order Prasiolales. Therefore, algal secondary chemistry is driven by its biogeography [5-7].

Prasiola crispa (Lightfoot) Meneghini (Figure 1), is a macroscopic terrestrial green algae which thalli of the pseuparenchymatic laminar form reaches $1 \times 0.5 \mathrm{~cm}$, forming a mass of 2.0 to $6 \mathrm{~cm}$ thickness, being the Antarctica'smost studied algae from the ecological perspective. This algae grows abundantly in terrestrial habitats of meltwater zones [8-10], and it is associated with marine bird colonies and seal aggregations areas [11]. Seaweeds, such as the Prasiolales order, contain a considerable quantity of phytosterols, however, few studies about its biological effects are found in the literature [12-14], especially those related to their pharmacological and toxicological potentials.

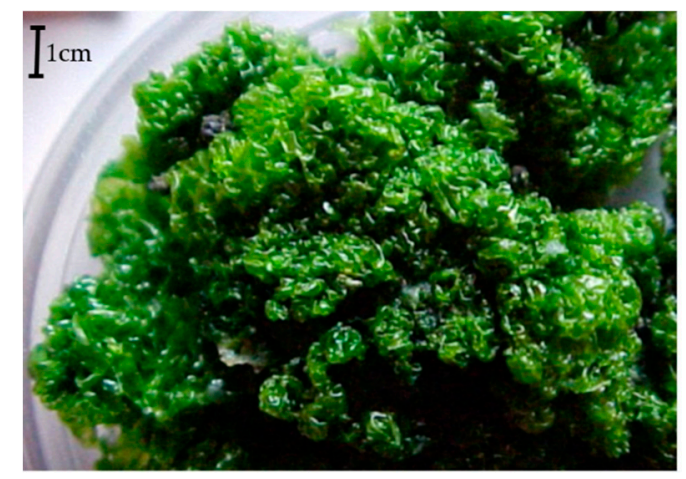

Figure 1. Prasiola crispa (Lightfoot) Meneghini collected in ice-free areas near to Arctowski Polish Base Region, Admiralty Bay, King George Island, Antarctica. Picture by Antônio Pereira Batista.

In this work, we have identified the mechanisms involved in the entomotoxic activity of Prasiola crispa's $n$-hexane extract. To accomplish this, we have employed $N$. cinerea cockroaches, which is a practical, inexpensive, and rapid model for neurotoxicological studies [15-17]. The entomotoxic effect of this algae was associated to the inner presence of different phytosterols in its extract, which reinforces its biotechnological potential as a natural insecticide [18,19].

\section{Results}

\subsection{Insecticidal Activity of n-Hexane Extract of Prasiola crispa}

The insecticidalactivity of HPC was confirmed in cockroaches, by injecting four doses of the extract $(100,200,400$, and $800 \mu \mathrm{g} / \mathrm{g}$ of body weight). All doses of HPC induced lethality in N. cinerea. The dose of $400 \mu \mathrm{g} / \mathrm{g}$ revealed the $\mathrm{LD}_{50}$, killing $50 \%$ of the animals in $24 \mathrm{~h}$ (Figure 2). In control assays, with the incubation with $10 \%$ DMSO alone, there was no animal death. 


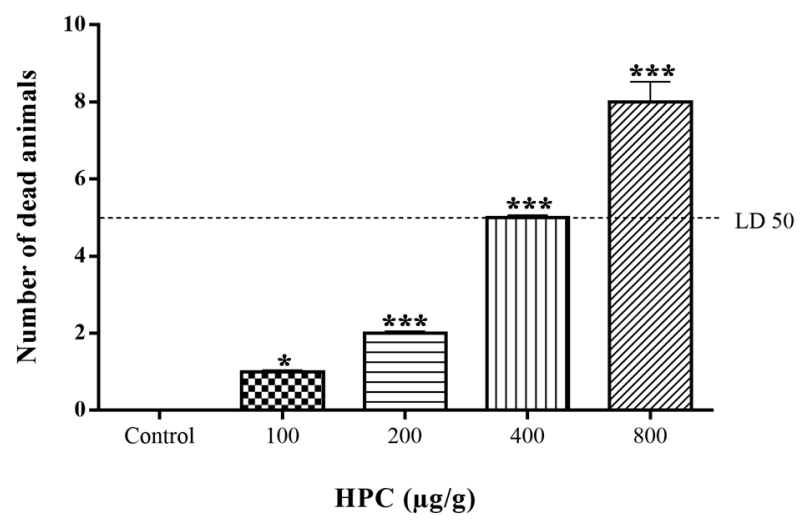

Figure 2. Insecticidal activity of $n$-hexane extract of $P$. crispa (HPC) on N. cinerea cockroaches. The results were expressed as the number of dead animals per dose. Statistical analyses were performed by one-way ANOVA followed by the Dunnett's test. ${ }^{*} p<0.05(n=3) ;{ }^{* * *} p<0.001(n=3)$, compared to control 10\% DMSO.

\subsection{The AChE Activity in Cockroach Brain Homogenates Was not Affected by HPC}

The evaluation of $N$. cinerea brain homogenates AChE activity, before and after treatment with different doses of HPC (100, 200, 400 and $800 \mu \mathrm{g} / \mathrm{g}$ of body weight), showed no alterations, when compared to the control (10\% DMSO). Data not shown.

\subsection{Effects of HPC on the Cockroach's Heart Rate}

The assay of HPC (100-800 $\mu \mathrm{g} / 200 \mu \mathrm{L})$, on cockroach semi-isolated heart preparation induced a significative decrease of heartbeats, only with the maximum concentration (Figure 3). On this set of protocols, the incubation of the preparation with $10 \%$ DMSO, induced only a slight decrease in the heart frequency. However, when HPC $800 \mu \mathrm{g} / 200 \mu \mathrm{L}$ was added to the preparation, there was a negative chronotropic modulation of heart rates, with a final inhibition of about $50 \%$, in $30 \mathrm{~min}$ recordings ( $n=9, p<0.05$ ) (Figure 3$)$. The washout of the preparation with insect saline, reversed the HPC inhibitory activity, leading the rates to control levels. The application of Trichlorfon (Tn) $0.5 \mu \mathrm{g} / 200 \mu \mathrm{L}$, as a positive cholinergic control, inhibited the cardiac rhythm similarly to HPC, although irreversibly (Figure 3).

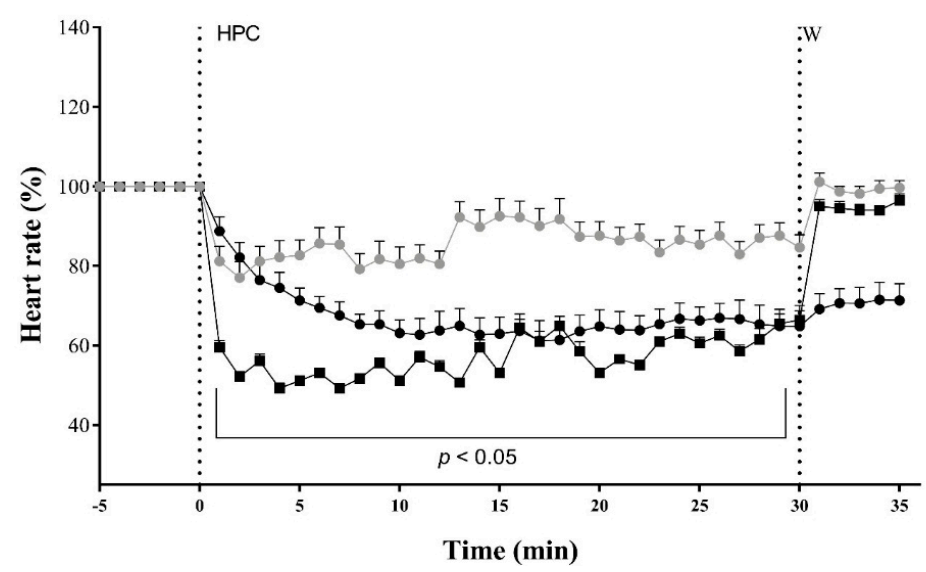

Figure 3. Cardiotoxic effect of HPC onN. cinerea cockroaches. The recordings were made during $30 \mathrm{~min}$. Statistical analyses were performed using two-way ANOVA followed by Bonferroni's test compared to control. $p<0.05(n=9)$; Control: $10 \%$ DMSO in insect saline. 


\subsection{Effects of HPC on Cockroach Grooming Activity}

In $10 \%$ DMSO-injected cockroaches, the mean time of continuous grooming was $73.2 \pm 1.2 \mathrm{~s} / 30 \mathrm{~min}$ for legs and $75.2 \pm 1.2 \mathrm{~s} / 30 \mathrm{~min}$ for antennae ( $n=30$, respectively). Overall, the injection of HPC (100, 200,400 and $800 \mu \mathrm{g} / \mathrm{g}$ body weight) on $N$. cinerea significantly affected the animals' grooming activity. At lower concentrations, HPC (100 and $200 \mu \mathrm{g} / \mathrm{g})$ induced a significative increase in the grooming activity of legs and antennae $(n=30, p<0.001)$. For $100 \mu \mathrm{g} / \mathrm{g}$, the increment of grooming activity of legs and antennae were $400 \pm 0.7 \mathrm{~s} / 30 \mathrm{~min}$ and $388 \pm 2.8 \mathrm{~s} / 30 \mathrm{~min}$, respectively. At $200 \mu \mathrm{g} / \mathrm{g}$, the values for legs and antennae's grooming were $322 \pm 0.7 \mathrm{~s} / 30 \mathrm{~min}$ and $157.8 \pm 1.8 \mathrm{~s} / 30 \mathrm{~min}$, respectively (Figure 4). At the highest dose, a complete inhibition was observed on grooming activity of legs and antennae of cockroaches (Figure 4). The injection of HPC, at $400 \mu \mathrm{g} / \mathrm{g}$, induced a significant decrease on grooming activity of antennae $(53.9 \pm 1.0 \mathrm{~s} / 30 \mathrm{~min} ; n=30)$. On the other hand, at the same concentration, HPC increased significantly the grooming of legs $(277.6 \pm 0.6 \mathrm{~s} / 30 \mathrm{~min} ; n=30)$.

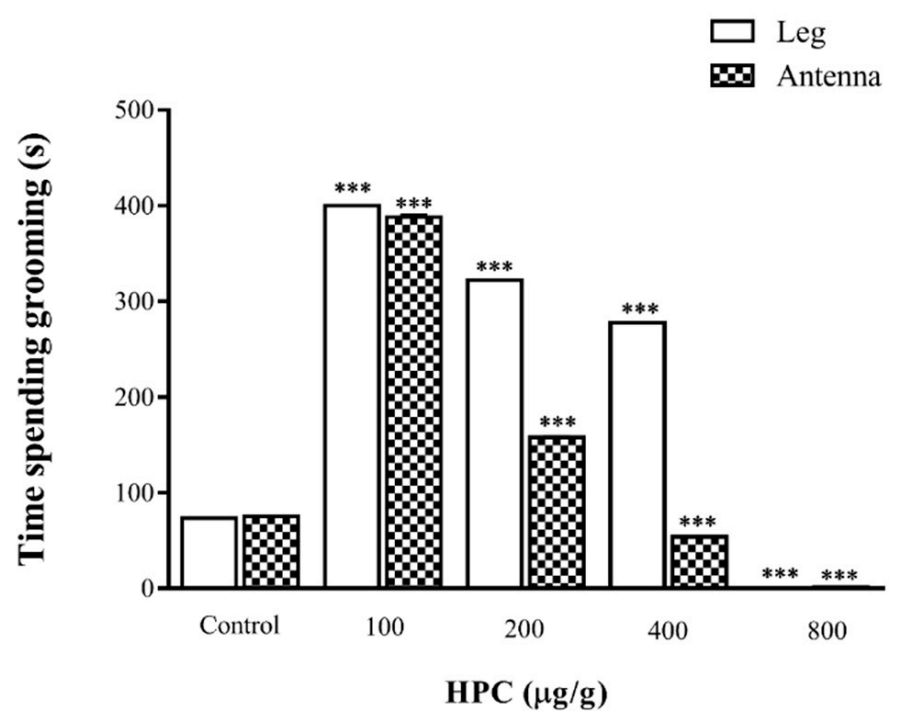

Figure 4. Effect of HPC on grooming behavior of $N$. cinerea cockroaches. The grooming activity was recorded during $30 \mathrm{~min}$ and the results were expressed as mean \pm S.E.M. of the total time of grooming (in seconds). Notice the increase of grooming activity in lower HPC doses, followed by a decrease in the activity with the highest dose. The data were analyzed by one-way ANOVA followed by the Dunnett's test compared to control. ${ }^{* * *} p<0.001(n=30)$.

\subsection{Neuromuscular Blockade Induced by HPC in N. cinerea Cockroaches}

In control conditions, using only $10 \% \mathrm{DMSO}$, there was no alteration in the muscle twitch tension of $N$. cinerea, in $120 \mathrm{~min}$ recordings $(n=6)$ (Figure 5A). Overall, the injection of HPC $(100,200,400$ and $800 \mu \mathrm{g} / \mathrm{g}$ body weight) induced a dose- and time-dependent neuromuscular inhibition in $120 \mathrm{~min}$ recordings $(n=6)$ (Figure 5A). When 100 and $200 \mu \mathrm{g} / \mathrm{g}$ HPC were assayed, there were $80 \pm 0.8 \%$ and $65 \pm 1.4 \%$ maximal blockages, respectively, in 120 min recordings $(n=6)$ (Figure 5A). For HPC $400 \mu \mathrm{g} / \mathrm{g}$, the inhibitory effect started after $10 \mathrm{~min}$, and was progressive until a complete inhibition being reached after $80 \mathrm{~min}(n=6)$ (Figure 5A). At $800 \mu \mathrm{g} / \mathrm{g}$, HPC produced a fast and progressive neuromuscular blockage, which was complete at $10 \mathrm{~min}$ (Figure 5A). In this set of protocols, the injection of the organophosphate compound $\mathrm{Tn} 0.5 \mu \mathrm{g} / \mathrm{g}$ body weight, induced $44 \pm 4 \%$ blockage, in $120 \mathrm{~min}$ recordings $(n=6)$ (Figure 5B). To investigate the influence of octopaminergic receptors in the neurotoxic activity of HPC, we assayed phentolamine $10 \mu \mathrm{g} / \mathrm{g}$ body weight, a selective inhibitor of octopamine receptors. When phentolamine $10 \mu \mathrm{g} / \mathrm{g}$ was assayed alone, there was a $40 \pm 0.6 \%$ maximum blockade of the twitch tension, in $120 \mathrm{~min}$ recordings (Figure 5B). The injection of phentolamine $10 \mu \mathrm{g} / \mathrm{g}$ previously to HPC $800 \mu \mathrm{g} / \mathrm{g}$, prevented by 70\% the HPC $800 \mu \mathrm{g} / \mathrm{g}$ inhibitory activity (Figure 5B). Neuromuscular representative timeline traces of muscle twitch tension recordings are shown in Figure 5C. 

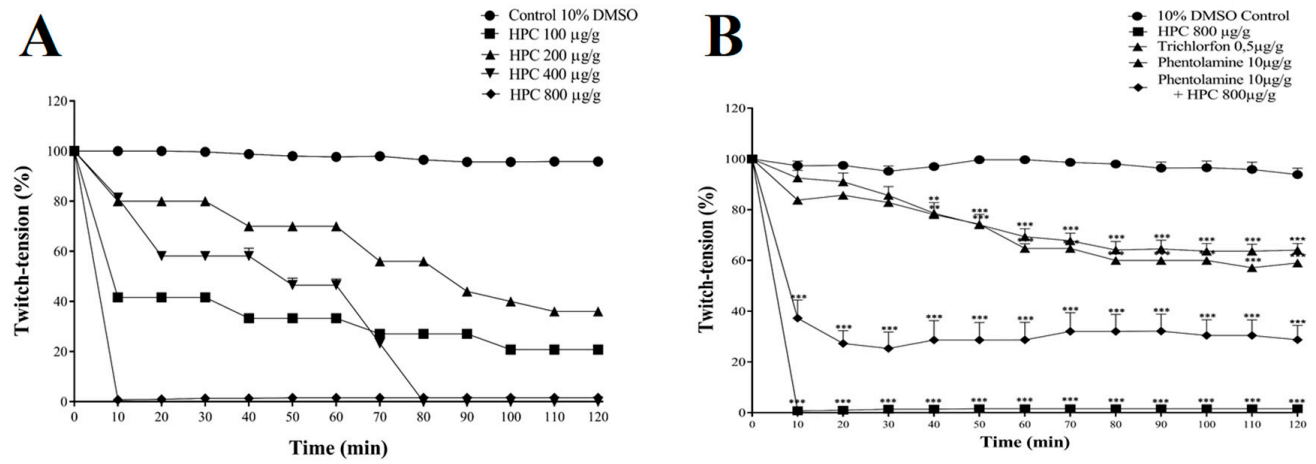

C

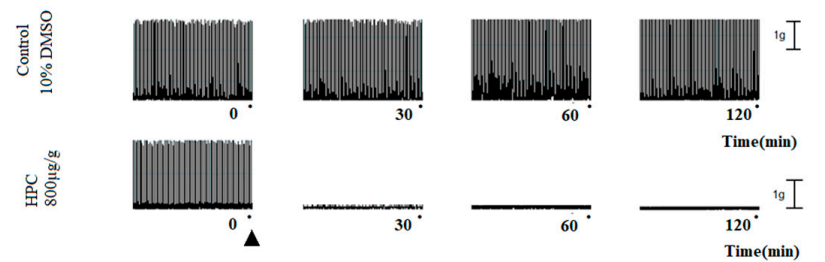

Figure 5. Neuromuscular blocking activity of HPC on N. cinerea cockroaches. The graph represents the mean \pm S.E.M of six experiments $(\mathbf{A}, \mathbf{B})$. On (A), the neuromuscular blockade induced by different doses of HPC. On (B), notice the prevention of the neuromuscular blockade induced by HPC $800 \mu \mathrm{g} / \mathrm{g}$ body weight, by the previous incubation of phentolamine $10 \mu \mathrm{g} / \mathrm{g}$ in the preparation. On (B), the incubation of Tn $0.5 \mu \mathrm{g} / \mathrm{g}$ induced a similar inhibition compared to HPC in $120 \mathrm{~min}$ recordings. On (C), representative traces of the insect neuromuscular recordings in control 10\% DMSO condition and during the onset of HPC $(800 \mu \mathrm{g} / \mathrm{g})$ activity. Statistical analyses were performed by two-way ANOVA followed by Bonferroni's test compared to control. Control: $10 \%$ DMSO in insect saline; $\mathbf{\Delta}$ : HPC $800 \mu \mathrm{g} / \mathrm{g}$; Tn: trichlorfon; ${ }^{* *} p<0.01 ;{ }^{* * *} p<0.001(n=6)$.

\subsection{Phytosterols Identified in the Prasiola crispa n-Hexane Extract}

The most abundant steroidal componentspresented in the extract (Figure 6). Campesterol, $\beta$-sitosterol, and stigmasterol (about 10-20\% of the extract), were identified based on comparisons with standards (Sigma/Aldrich Products) and/or literature [20] (Table 1).

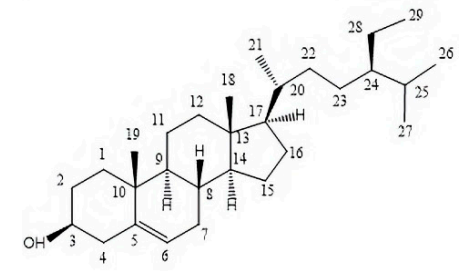

$\beta$-sitosterol

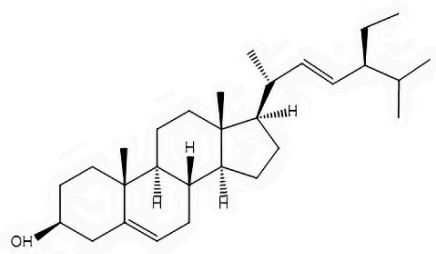

Stigmasterol

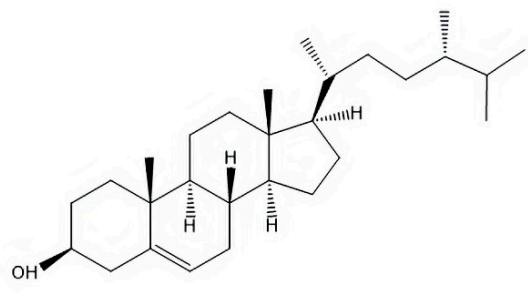

\section{Campesterol}

Figure 6. Major phytosterols identified in the Prasiola crispan-Hexane extract ( $\delta$ in ppm, J in Hz). 
Table 1. Selected $13 \mathrm{C}$ - and $1 \mathrm{H}$ data $(300 \mathrm{MHz}$ in $\mathrm{CDCl} 3)$ of the most abundant sterols found in Prasiola crispan-hexane extract.

\begin{tabular}{|c|c|c|c|c|c|c|}
\hline $\mathrm{C} / \mathrm{H}$ & & Campesterol & & $\beta$-sitosterol & & Stigmasterol \\
\hline $\mathrm{C} 3$ & 71.82 & $3.66(1 \mathrm{H}, \mathrm{m})$ & 71.71 & $3.66(1 \mathrm{H}, \mathrm{m})$ & 71.29 & $3.66(1 \mathrm{H}, \mathrm{m})$ \\
\hline C6 & 122.45 & $5.33(1 \mathrm{H} ; \mathrm{d} ; 1.2)$ & 119.80 & $5.35(1 \mathrm{H}, \mathrm{s})$ & 121.60 & $5.37(1 \mathrm{H} ; \mathrm{d} ; 5.33)$ \\
\hline C18 & 11.96 & $0.68(3 \mathrm{H}, \mathrm{s})$ & 11.94 & $0.68(3 \mathrm{H}, \mathrm{s})$ & 11.21 & $0.70(1 \mathrm{H}, \mathrm{s})$ \\
\hline C19 & 19.21 & $1.00(3 \mathrm{H}, \mathrm{s})$ & 18.28 & $1.00(3 \mathrm{H}, \mathrm{s})$ & 20.80 & $1.01(3 \mathrm{H}, \mathrm{s})$ \\
\hline $\mathrm{C} 21$ & 18.61 & $0.90(3 \mathrm{H} ; \mathrm{d} ; 6.5)$ & 18.83 & $0.92(3 \mathrm{H} ; \mathrm{d} ; 1.5)$ & 21.06 & $1.02(3 \mathrm{H}, \mathrm{s})$ \\
\hline $\mathrm{C} 22$ & & & & & 138.13 & $5.16(1 \mathrm{H} ; \mathrm{dd} ; 15.0 ; 8.09)$ \\
\hline $\mathrm{C} 23$ & & & & & 129.21 & $5.16(1 \mathrm{H} ; \mathrm{dd} ; 14.4 ; 8.09)$ \\
\hline $\mathrm{C} 26$ & 19.61 & $0.85(3 \mathrm{H} ; \mathrm{d} ; 2.2)$ & 19.48 & $0.80(3 \mathrm{H} ; \mathrm{d} ; 3.7)$ & 20.40 & $0.80(3 \mathrm{H} ; \mathrm{d} ; 3.7)$ \\
\hline $\mathrm{C} 27$ & 18.56 & $0.79(3 \mathrm{H} ; \mathrm{d} ; 3.6)$ & 20.40 & $0.84(3 \mathrm{H} ; \mathrm{d} ; 2.4)$ & 19.48 & $0.84(3 \mathrm{H} ; \mathrm{d} ; 2.4)$ \\
\hline $\mathrm{C} 28$ & 14.00 & $0.77(3 \mathrm{H} ; \mathrm{d} ; 3.7)$ & & & & \\
\hline $\mathrm{C} 29$ & & & 12.30 & $0.85(3 \mathrm{H} ; \mathrm{d} ; 2.2)$ & 12.20 & $0.80(3 \mathrm{H} ; \mathrm{d} ; 3.7)$ \\
\hline
\end{tabular}

\subsection{Effects of Phytosterols on Nerve-Muscle Preparation of Cockroaches}

The main compounds identified in the P. crispa extract were $\beta$-sitosterol, campesterol, and stigmasterol [20], which were assayed in the cockroach nerve-muscle preparations for comparison against the whole extract. Overall, the assay of the phytosterols isolated, at $80 \mu \mathrm{g} / \mathrm{g}$ body weight, resulted in a mimicking of the neuromuscular blockade induced by the algae whole n-hexane extract. When $\beta$-sitosterol was incubated, there was $45 \pm 1.6 \%$ inhibition of the muscle twitchesat $40 \mathrm{~min}$ and a complete blockade in 120 min recordings $(n=6)$ (Figure 7). The analysis of campesterol and stigmasterol resulted in $80 \pm 2.8 \%$ and $65 \pm 3.0 \%$ neuromuscular inhibition in $120 \mathrm{~min}$, respectively (Figure 7). In this set of protocols, when all the phytosterols were gathered and assayed in combination, at $80 \mu \mathrm{g} / \mathrm{g}$ body weight each there was an improvement of the blocking activities, resulting in a complete inhibition of the muscle twitches at $90 \mathrm{~min}$ (Figure 7).

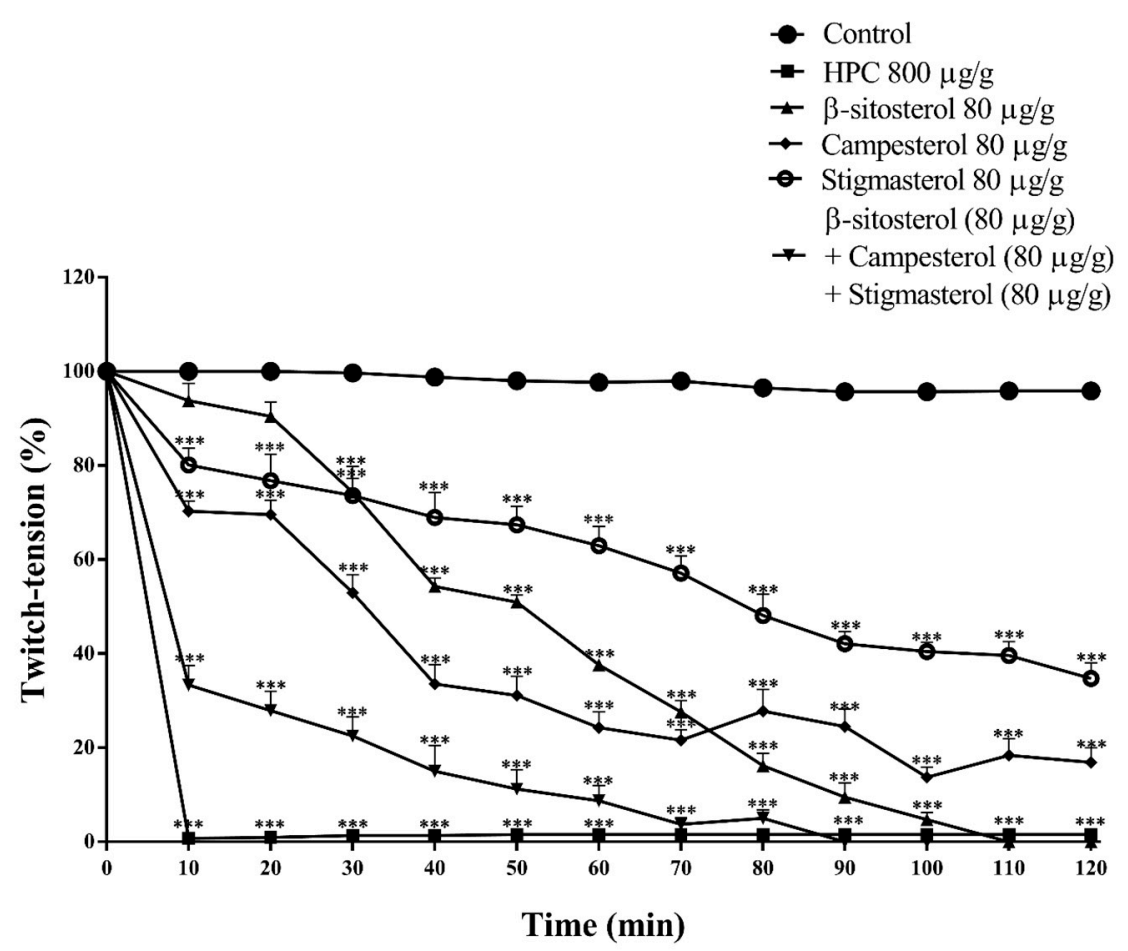

Figure 7. Neuromuscular blocking activities induced by $\beta$-sitosterol, campesterol, and stigmasterol in $N$. cinerea cockroaches. The results are expressed as mean \pm S.E.M. Statistical analyses were performed by two-way Anova followed by Bonferroni's test compared to control. ${ }^{* * *} p<0.001(n=6)$. 


\section{Discussion}

In this study we demonstrated part of the mechanisms involvedin the entomotoxic activity of P. crispan-hexane extract. In addition, we identified the main chemical constituents involved in Prasiola crispa toxic activity to insects, as being the following phytosterols: $\beta$-sitosterol, campesterol, and stigmasterol. The results obtained in different neurophysiological systems of $N$. cinerea cockroaches are discussed in detail therein, and reinforces the potential of this Antarctic alga as a natural insecticide.

In our experimental conditions, the exposure of cockroaches to HPC unveiled its insecticidal activity, agreeing with previous studies of our group using Drosophila melanogaster and N. cinerea [13]. Physiologically, the lethality induced by a natural or synthetic insecticide is a result of a chemical interaction with one of the five biological systems of the insect, which comprises, the nervous system, the production of energy, the production of cuticle, the endocrine system and water balance [21]. In the case of the nervous system, the most common target for insecticides, frequently, but not exclusively, is the insect nerve acetylcholinesterase (AChE). Under our experimental conditions, HPC displayed no activity over the brain AChE of N. cinerea cockroaches. Although, HPC did not alter the cockroach's brain homogenates AChE activity, the identified phytosterols, $\beta$-sitosterol, campesterol, and stigmasterol are known to modulate this enzyme in different extents [22-24]. Phytosterols, are a subgroup of steroids having close structure resemblance with cholesterol and are widely distributed in herbs, fungi and animals [25]. Cholesterol, is the major constituent of eukaryotic cellular membranes, acting as secondary messenger, regulating cell signaling and physiological processes [23]. At this point, we cannot infer about the precise mechanism involved in the HPC-phytosterol-induced neurotoxicity in N. cinerea cockroaches. However, in some insect species, including cockroaches, cholesterolcan affect hormones and development [26]. Therefore, the absence of HPC activity over the insect AChE may be explained by the peculiar modulation that phytosterols exert against this enzyme. For example, while campesterol exhibits good anti-cholinesterase activity, stigmasterol and its correlate $\beta$-stigmasterol show to have weak bonding with AChE proteins in molecular docking analysis [27]. Taken together, the insecticide activity of HPC on cockroaches may not rely exclusively on an anti-AChE activity per se, but may be a result of the direct interaction of its chemical compounds at different targets in the insect neurophysiological system.

HPC induced cardiotoxicity in N. cinerea, particularly the negative chronotropic activity in semi-isolate heart preparations. This inhibitory activity of HPC resembles those induced by the cholinergic agent Tn and the Rhinella icterica toad poison [16]. In this regard, the insect heart receives innervation from several sources, especially from cholinergic [28] and octopaminergic nerves [29]. Octopamine (OCT) is the main cardio-modulatory neurohormone in insects and induce biphasic effects at cardiac rhythm $[29,30]$. Similar to other biogenic amines, octopamine signaling is mediated through binding to distinct receptors that belong to a family of metabotropic $G$ protein-coupled receptors (GPCRs) [31]. The excitatory activity of octopamine on insect heart is related to the octopaminergic receptor subtype 2 (octopamine2) [32]. On the other hand, octopamine 1 receptors evokes the inhibition of cardiac rhythmic in insects [33,34]. Acetylcholine and AChE inhibitors also affect the heart rate in insects, inducing an increase or decrease of heart-beats, depending on the concentration [35-37]. Recently, our group have demonstrated the striking interaction between cholinergic-octopaminergic neurotransmission in $N$. cinerea [38]. We cannot rule out about the exact mechanism involved in the negative chronotropic activity induced by HPC, in N. cinerea hearts. However, since phytosterols are proven to be cholinergic agents, the activation of a cholinergic-octopaminergic neurotransmission by HPC at the insect heart levels cannot be disregarded.

In addition, HPC caused profound alterations on N. cinerea behavior, as demonstrated by the significant modulation of grooming activity. Despite the neural center involved in grooming activity is not completely identified, it is well established that monoamines, such as dopamine and octopamine, participate in the orchestration of this behavior, in insects [39]. In our experimental conditions, the increase of leg grooming activity rather than the antennae, in HPC-treated cockroaches, suggests a direct involvement of the neurotransmitter octopamine [40,41]. This result agreed with the inhibitory 
activity of HPC on heart frequency [38] and demonstrates the influence of the neurotransmitter octopamine on the deregulation of N. cinerea physiological and behavioral functions, in the presence of the Antarctic algae extract.

HPC also induced a severe impairment of neuromuscular function of N. cinerea. The inhibitory activity caused by HPC on cockroach neuromuscular function was also mimicked by the isolated phytosterols ( $\beta$-sitosterol, campesterol, and stigmasterol). In insects, glutamate is an excitatory neuromuscular transmitter and $\gamma$-aminobutyric acid (GABA) is the inhibitory one [42]. It is worth of notice that, in our experimental cockroach model, the neuromuscular twitches were evoked by stimulating a cholinergic nerve, named nerve 5 (Watson, 1986). Along nerve 5 , the activity is conducted centrally (coming from afferent signals of sensila) or peripherally, toward the methatoracic ganglion through monosynapticaly connected motorneurons via cholinergic [43] and octopaminergic synapsis [31]. The demonstration that phentolamine prevents the HPC neuromuscular blocking activity, suggests that an octopaminergic pathway must be involved in the algae extract peripheral toxicity. Besides, octopamine also may participate in the modulation of neuromuscular junction induced by HPC. The role of this monoamine in insects as a neurotransmitter, neurohormone, and neuromodulator is well established $[44,45]$. Octopamine is identified in a class of neurons of the metathoracic, abdominal, and subesophageal ganglia, which have been termed dorsal unpaired median (DUM) neurons [46,47]. The release of octopamine from dorsal unpaired neurons-DUM also coordinate the insect neuromuscular transmission, muscle contraction and direct influences other peripheral organs [48].

In addition, the evidence that the organophosphate Tn inhibits the cockroach neuromuscular junctions, similarly to other cholinergic compounds [17], corroborates the striking cooperation between octopaminergic and cholinergic pathways in the HPC entomotoxic activity at N. cinerea. Thus, we suggest that, in our experimental conditions, the acetylcholine-octopamine relationship would be involved in a direct modulation of the insect neuromuscular transmission, by altering the glutamatergic and GABAergic synapsis. Ultimately, this interaction of HPC with cockroach peripheral nervous system would cause lethargy of the animals, and is crucial for the insecticidal activity of HPC. Thus, the indirect effects of the isolated phytosterols at the insect neuromuscular junctions would follow the same mechanisms of organophosphate agents. Secondarily, their steroidal activities would directly reinforce the octopaminergic synapsis, improving the neuromuscular blocking activity. Further support for this hypothesis is the scientific observation that in membranes, cholesterol significantly modulates the stability, ligand-binding properties and function of several GPCRs [49]. In addition, since OCT release and reuptake systems are commanded by GPCRs in insects and are considered to be important targets for novel insecticides [31], is not far from mind to expect a direct interaction of HPC phytosterols at OCT receptors to improve its insecticidal activity.

Altogether, the results presented here corroborate the entomotoxic potential of Prasiola crispa Antarctic algae. They also revealed the presence of phytosterols and the involvement of these chemical compounds in the algae toxic activity in insects, potentially by an octopaminergic-cholinergic interaction. Further phytochemical-combined with a bioguided analysis of the HPC will unveil novel bioative compounds that might be accessory for the insecticide activity of the algae.

\section{Material and Methods}

\subsection{Experimental Animals}

All experiments were performed on both sexes of adult Nauphoeta cinerea cockroaches (3-4 months after an adult molt). The animals were reared in laboratory conditions of controlled temperature $\left(22-25^{\circ} \mathrm{C}\right)$ and photoperiod 12:12 L:D. All cockroaches were provided with water and dog chow ad libitum.

\subsection{Reagents and Solutions}

Unless otherwise stated, all reagents were purchased from Sigma-Aldrich, Merck, Roche, Life Technologies or BioRad. Test-solutions were prepared daily by dilution in insect saline [50], immediately 
before use. The insect saline is a carbonate-buffered solution freshly prepared with the following composition in $\mathrm{mM}: \mathrm{NaCl}, 214 ; \mathrm{KCl}, 3.1 ; \mathrm{CaCl}_{2}, 9$; sucrose, 50; HEPES buffer, 5 and $\mathrm{pH}$ 7.2. To the biological assays with the n-hexane extract of $P$. crispa (HPC), a solution of $10 \%$ DMSO $(v / v)$ to insect saline was used for dissolving the compound immediately before tests. All drugs were injected into the third abdominal hemocoel segment of the cockroaches at a final volume of $20 \mu \mathrm{L}$ using a Hamilton syringe.

\subsection{Algae Material}

Prasiola crispa (Lightfoot) Meneghini was collected in ice-free areas Punta Ulmann, King George Island (62 $\left.04^{\prime} 55.6^{\prime \prime} \mathrm{S}, 58^{\circ} 21^{\prime} 10.3^{\prime \prime} \mathrm{W}\right)$, Antarctica. Dried vouchers on herbarium sheets are deposited at the SPF Herbarium in São Paulo, Brazil voucher (SPF428304). Seaweeds were dried in a dark chamber with air circulation at $40^{\circ} \mathrm{C}$ and stored in dark plastic bagsin a freezer $\left(-20^{\circ} \mathrm{C}\right)$. Additional screening, including washout with distilled water was performed for removal of waste and other materials before further phytochemical assays.

\subsection{Extract Preparation}

Dried seaweeds were powdered in knife grinder (Marconi, Model MA-680, Piracicaba, SP, Brazil) and extracted with different solvents including methanol, dichloromethane, ethyl acetate, n-hexane or acetone $(4 \times 1.0 \mathrm{~L})$, respectively, at room temperature. The resulting extracts were evaporated under reduced pressure and stored at $-4^{\circ} \mathrm{C}$, until biological experiments or chemical analysis.A preliminary insecticide assay was carried out with $N$. cinerea cockroaches, using all the different extracts. After that, theHPC extract was chosen because of its best potency in terms of insecticidal activity.

\subsection{Assay for Insecticidal Activity}

The insecticidal activity of HPC against $N$. cinerea was carried out according to Kagabu et al. [51]. Different concentrations of HPC (100, 200, 400, and $800 \mu \mathrm{g} / \mathrm{g}$ of animal) and 10\% DMSO in insect saline were injected between the third and the fourth abdominal segments of cockroaches. All experiments were made in triplicate; for each dose assayed, ten cockroaches were used. The animals were kept at controlled temperature conditions $\left(22-25^{\circ} \mathrm{C}\right)$, with water and food ad libitum, and the survival rates recorded after $24 \mathrm{~h}$ exposure to the test compounds.

\subsection{Assay for Insect Acetylcholinesterase Activity}

The in vitro activity of AChE was evaluated according to Stürmer et al. [50]. Six animals were treated with different doses of HPC $(100,200,400$ and $800 \mu \mathrm{g} / \mathrm{g}$ body weight). The amount of protein in the samples was measured according to the method of [52]. The results were expressed as percentage of milliunits of AChE per milligram of protein ( $\mathrm{mU} / \mathrm{mg}$ protein). One milliunit of $\mathrm{AChE}$ was defined as the amount of enzyme.

\subsection{Semi-Isolated Cockroach Heart Preparation}

The semi-isolated cockroach heart bioassay was mounted according to Carrazoni et al. [38]. Heart beat frequencies were monitored during 30 min under a stereoscopic microscope (Olympus, Damstat, Germany). Nine cockroaches were used for each group, for each different treatment.

\subsection{Grooming Activity}

The grooming behavior of cockroaches was evaluated as previous described [41,50]. Different concentrations of HPC (100, 200, 400 and $800 \mu \mathrm{g} / \mathrm{g}$ of animal) or 10\% DMSO in insect saline were used. The assays were carried out $2-8 \mathrm{~h}$ after the beginning of the light cycle and in controlled conditions of temperature $\left(22-25^{\circ} \mathrm{C}\right)$. 


\subsection{In Vivo Cockroach Metathoracic Coxal-Adductor Nerve-Muscle Preparation}

The analysis of cockroach neuromuscular function was mounted essentially as described elsewhere [53]. Twitch-tensions were recorded, digitized and retrieved using a computer-based software AQCAD (AVS Instruments, São Carlos, SP, Brazil). Data were further analyzed using the software ANCAD (AVS Instruments, São Carlos, SP, Brazil). The data were expressed as a percentage of the neuromuscular twitch tension, before treatments.

\subsection{Chemical Analysis}

An aliquot of Prasiola crispa $n$-hexane extract (10 mg) was analyzed by NMR spectra (proton and carbon) on Varian-Unity Plus $300 \mathrm{MHz}$ spectrometer, employing $\mathrm{CDCl}_{3}$ (99.8\%, Merck, Whitehouse Station, NJ, USA), as a solventand TMS as internal standard. Chemical shifts were reported in $\delta(\mathrm{ppm})$ and coupling constants $(\mathrm{J})$, in Hz. Multiplicities of ${ }^{13} \mathrm{C}$ signals were obtained by APT. All solvents were of HPLC grade for extraction, fractionation and isolation of the sterols.TLC separations were carried out on Merck silica gel 60F-254 (0.2 mm) percolated aluminum plates. Once developed, the plates were visualized by spraying them with $2 \%$ ceric sulfate in sulfuric acid, followed by gentle heating. Fractionation was monitored by thin layer chromatography. Silica gel60 (Merck, 70-230 and 230-400 mesh), was used for column chromatography.

The hexanic extract was fractionated by column chromatographies on silica gel Merck 70-230 and 230-400 mesh, using hexane/ $\mathrm{CH}_{2} \mathrm{Cl}_{2}$ /ethyl acetate as eluent $\left(\mathrm{F}_{1}-\mathrm{F}_{30}\right)$. All fractions were abundant in sterols. The most abundant steroidal components were detected by NMR spectra (campesterol, $\beta$-sitosterol, and stigmasterol). The identification was based on NMR comparisons with standards (Sigma/Aldrich Products) and/or literature [54] (Table 1).

\subsection{Statistical Analysis}

Results were expressed as the mean \pm SEM. Statistical analysis wereconducted by One-way ANOVA followed by Dunnet (when more than two groups were analyzed) or Two-way ANOVA followed by Bonferroni (when more than two variables were analyzed) as post hoc. Statistics and graphs were made using the Software Graphpad Prism 6.0 (Software Inc., San Diego, CA, USA).

\section{Conclusions}

This study confirmed the biotechnological potential of the Antarctic algae P. crispa as a natural insecticide. The mechanism of entomotoxic activity involves the presence of phytosterols in the algae. The effects of HPC in both central and peripheral nervous system of N. cinerea potentially involves an octopaminergic-cholinergic interaction, that induce profound alterations in the insect behavior. The importance of octopamine to insect survival and the possible deregulation of this neurotransmission for the inner steroidal molecules present in the extract reinforces the importance of phytosterols in the insecticide activity of Prasiola crispan-hexane extract. Further phytochemicalcombined bioguided analysis of the HPC will unveil novel bioative compounds that might be accessory to the insecticidal activity of the algae.

Author Contributions: Funding acquisition and resources: A.B.P. and F.d.C.V.; Investigation, G.H.L., A.P.L., R.S.O., A.P.Z., C.G.M.d.A., Y.C.B., M.E.R., C.J.B.R. and V.L.; Supervision, C.A.D.B.; V.L.; Writing-original draft, P.d.B.V., V.L. and C.A.D.B.; review \& editing, R.S.O., A.P.L., P.d.B.V., and C.A.D.B.

Funding: This work was supported by grants from Instituto Nacional de Ciências e Tecnologia Antártico de Pesquisas Ambientais - INCT-APA.

Acknowledgments: This study was financed in part by the Coordenação de Aperfeiçoamento de Pessoal de Nível Superior - Brasil (CAPES) - Finance Code 001. The authors also thank Coordenação de Aperfeiçoamento de Pessoal de Nivel Superior (CAPES, Coordination for the Improvement of Higher Education Personnel) for financial support through the grants PRONEM/FAPERGS/CNPq 003/2011 and 063/2010 Toxinologia. G.H. Lorensi, R.S. Oliveira, A.P.Z., C.G.M. Almeida, A.P. Leal, M.E. Rosa and P.B. Vieira were supported by grants from CAPES. Y. C. Barreto was supported by a scholarship from the Fundação de Amparo à Pesquisa do Estado do Rio Grande do Sul (FAPERGS, Edital no. 187/2018). We are equally grateful to CNPq for Productivity Grant (301964/2018) 
awarded to Valéria Laneuville Teixeira and FAPERJ which awarded the merit of Rio de Janeiro state scientist to Teixeira (E-26/202.794/2018). The publication costs for this article were covered by a grant to C. A. Dal Belo from UNIPAMPA (Chamada Interna de Apoio ao Custeio de Publicação Científica de Fluxo Contínuo, no. 05/2019).

Conflicts of Interest: The authors declare no conflict of interest.

\section{References}

1. The Antarctic-Extreme Environments-Climate Policy Watcher. Available online: https://www.climatepolicy-watcher.org/extreme-environments/the-antarctic.html (accessed on 11 June 2019).

2. Kejna, M. Trends of air temperature of the Antarctic during the period 1958-2000. Pol. Polar Res. 2003, 24, 99-126.

3. Antarctic Environment-Australian Antarctic Division. Available online: http://www.antarctica.gov.au/ about-antarctica/environment (accessed on 11 June 2019).

4. Courtesy, P.; de Pesquisas Ambientais, A.; Headquarters, I.-A. Annual Activity Report; INCT-APA: Rio de Janeiro, Brazil, 2013.

5. Amsler, C.D. Algal Chemical Ecology; Springer: Berlin/Heidelberg, Germany, 2008; Volume 468.

6. Leal, M.C.; Munro, M.H.G.; Blunt, J.W.; Puga, J.; Jesus, B.; Calado, R.; Rosa, R.; Madeira, C. Biogeography and biodiscovery hotspots of macroalgal marine natural products. Nat. Prod. Rep. 2013, 30, 1380-1390. [CrossRef] [PubMed]

7. De Broyer, C.; Koubbi, P.; Griffiths, H.J.; Raymond, B.; Acoz, C.; Griffiths, H.; Raymond, B.; Udekem, C.; Van de Putte, A.; Danis, B.; et al. SCAR-Marine Biodiversity Information Network. In Biogeographic Atlas of the Southern Ocean; Scientific Committee on Antarctic Research: Cambridge, UK, 2014.

8. Rindi, F.; McIvor, L.; Sherwood, A.R.; Friedl, T.; Guiry, M.D.; Sheath, R.G. Molecular Phylogeny of the Green Algal Order Prasiolales (Trebouxiophyceae, Chlorophyta) 1. J. Phycol. 2007, 43, 811-822. [CrossRef]

9. Carvalho, E.L.; Wallau, G.L.; Rangel, D.L.; Machado, L.C.; Pereira, A.B.; Victoria, F.D.C.; Boldo, J.T.; Pinto, P.M. Phylogenetic positioning of the Antarctic alga Prasiola crispa (Trebouxiophyceae) using organellar genomes and their structural analysis. J. Phycol. 2017, 53, 908-915. [CrossRef] [PubMed]

10. Kosugi, M.; Katashima, Y.; Aikawa, S.; Tanabe, Y.; Kudoh, S.; Kashino, Y.; Koike, H.; Satoh, K. Comparative Study on the Photosynthetic Properties of Prasiola (Chlorophyceae) and Nostoc (Cyanophyceae) from Antarctic and Non-Antarctic Sites 1. J. Phycol. 2010, 46, 466-476. [CrossRef]

11. Kovácik, L.; Pereira, A.B. Green alga Prasiola crispa and its lichenized form Mastodia tesselata in Antarctic environment: General aspects. Beiheft. Nova Hedwigia 2001, 123, 465-478.

12. Marinho RD, S.S.; Ramos CJ, B.; Leite JP, G.; Teixeira, V.L.; de Palmer Paixão IC, N.; Dal Belo, C.A.; Pereira, A.B.; Pinto, A.M.V. Antiviral activity of 7-keto-stigmasterol obtained from green Antarctic algae Prasiola crispa against equine herpesvirus 1. J. Appl. Phycol. 2017, 29, 555-562. [CrossRef]

13. Zemolin, A.P.P.; Cruz, L.C.; Paula, M.T.; Pereira, B.K.; Albuquerque, M.P.; Victoria, F.C.; Pereira, A.B.; Posser, T.; Franco, J.L. Toxicity induced by Prasiola crispa to fruit fly Drosophila melanogaster and cockroach Nauphoeta cinerea: Evidence for Bioinsecticide action. J. Toxicol. Environ. Health Part A 2014, 77, 115-124. [CrossRef]

14. Da Silva, A.C.R.; Pires, A.M.G.; Ramos, C.J.B.; Sanchez, E.F.; Cavalcanti, D.N.; Teixeira, V.L.; Fuly, A.L. The seaweed Prasiola crispa (Chlorophyta) neutralizes toxic effects of Bothrops jararacussu snake venom. J. Appl. Phycol. 2017, 29, 781-788. [CrossRef]

15. Carrazoni, T.; de Brum Vieira, P.; da Silva, P.A. Mechanism of the Entomotoxic Activity Induced by Araucaria Angustifolia Methanolic Extract in Nauphoeta Cinerea Lobster Cockroaches. J. Bot. Res. 2017, 1, 38-49.

16. Leal, A.P.; Oliveira, R.S.; Perin, A.P.A.; Borges, B.T.; de Brum Vieira, P.; dos Santos, T.G.; Vinadé, L.; Valsecchi, C.; Dal Belo, C.A. Entomotoxic activity of Rhinella icterica (Spix, 1824) toad skin secretion in Nauphoeta cinerea cockroaches: An octopamine-like modulation. Pestic. Biochem. Physiol. 2018, 148, 175-181. [CrossRef] [PubMed]

17. Dos Santos, D.S.; Rosa, M.E.; Zanatta, A.P.; Oliveira, R.S.; de Almeida, C.G.M.; Leal, A.P.; Sanz, M.; Fernandes, K.A.; de Souza, V.Q.; de Assis, D.R. Neurotoxic effects of sublethal concentrations of cyanobacterial extract containing anatoxin-a (s) on Nauphoeta cinerea cockroaches. Ecotoxicol. Environ. Saf. 2019, 171, 138-145. [CrossRef] [PubMed] 
18. Chaubey, M.K. Role of phytoecdysteroids in insect pest management: A review. J. Agron. 2018, 17, 1-10. [CrossRef]

19. Kortbeek, R.W.J.; van der Gragt, M.; Bleeker, P.M. Endogenous plant metabolites against insects. Eur. J. Plant Pathol. 2019, 154, 67-90. [CrossRef]

20. Baker, B.J.; Amsler, C.D.; McClintock, J.B. Macroalgal chemical defenses in polar marine communities. In Algal Chemical Ecology; Springer: Berlin/Heidelberg, Germany, 2008; pp. 91-103.

21. Rattan, R.S. Mechanism of action of insecticidal secondary metabolites of plant origin. Crop Prot. 2010, 29, 913-920. [CrossRef]

22. Gade, S.; Rajamanikyam, M.; Vadlapudi, V.; Nukala, K.M.; Aluvala, R.; Giddigari, C.; Karanam, N.J.; Barua, N.C.; Pandey, R.; Upadhyayula, V.S. V Acetylcholinesterase inhibitory activity of stigmasterol \& hexacosanol is responsible for larvicidal and repellent properties of Chromolaena odorata. Biochim. Biophys. Acta (BBA)-Gen. Subj. 2017, 1861, 541-550.

23. Ayaz, M.; Junaid, M.; Ullah, F.; Subhan, F.; Sadiq, A.; Ali, G.; Ovais, M.; Shahid, M.; Ahmad, A.; Wadood, A. Anti-Alzheimer's studies on $\beta$-sitosterol isolated from Polygonum hydropiper L. Front. Pharmacol. 2017, 8, 697. [CrossRef] [PubMed]

24. Elufioye, T.O.; Obuotor, E.M.; Agbedahunsi, J.M.; Adesanya, S.A. Anticholinesterase constituents from the leaves of Spondias mombin L. (Anacardiaceae). Biol. Targets Ther. 2017, 11, 107. [CrossRef]

25. Wright, C.W.; Anderson, M.M.; Allen, D.; Phillipson, J.D.; Kirby, G.C.; Warhurst, D.C.; Chang, H.R. Quassinoids exhibit greater selectivity against Plasmodium falciparum than against Entamoeba histolytica, Giardia intestinalis or Toxoplasma gondii in vitro. J. Eukaryot. Microbiol. 1993, 40, 244-246. [CrossRef]

26. Noriega, F.G. Juvenile hormone biosynthesis in insects: What is new, what do we know, and what questions remain? Int. Sch. Res. Not. 2014, 2014. [CrossRef]

27. Rohit, M.; Ashok, T.; Vijaykumar, R.; Kashniyal, K. Molecular docking study of cassia tora, brassica campestris and calotropis procera as acetylcholinesterase inhibitor. Indian J. Pharm. Educ. 2016, 50, 116-122. [CrossRef]

28. Miller, T. Response of cockroach cardiac neurons to cholinergic compounds. J. Insect Physiol. 1968, 14, 1713-1717. [CrossRef]

29. Papaefthimiou, C.; Theophilidis, G. Octopamine-A single modulator with double action on the heart of two insect species (Apis mellifera macedonica and Bactrocera oleae): Acceleration vs. inhibition. J. Insect Physiol. 2011, 57, 316-325. [CrossRef] [PubMed]

30. Papaefthimiou, C.; Theophilidis, G. An in vitro method for recording the electrical activity of the isolated heart of the adult Drosophila melanogaster. Vitr. Cell. Dev. Biol. 2001, 37, 445-449. [CrossRef]

31. Farooqui, T. Review of octopamine in insect nervous systems. Open Access Insect Physiol. 2012, 4, 1. [CrossRef]

32. Evans, P.D.; Robb, S. Octopamine receptor subtypes and their modes of action. Neurochem. Res. 1993, 18, 869-874. [CrossRef] [PubMed]

33. Evans, P.D. Multiple receptor types for octopamine in the locust. J. Physiol. 1981, 318, 99-122. [CrossRef] [PubMed]

34. Evans, P.D.; Maqueira, B. Insect octopamine receptors: A new classification scheme based on studies of cloned Drosophila G-protein coupled receptors. Invertebr. Neurosci. 2005, 5, 111-118. [CrossRef] [PubMed]

35. Pitman, R.M. Transmitter substances in insects: A review. Comp. Gen. Pharmacol. 1971, 2, 347-371. [CrossRef]

36. Rodríguez, V.; Mori, B.; Dörr, F.A.; Dal Belo, C.A.; Colepicolo, P.; Pinto, E. Effects of a cyanobacterial extract containing-anatoxin-a (s) on the cardiac rhythm of Leurolestes circunvagans. Rev. Bras. Farmacogn. 2012, 22, 775-781. [CrossRef]

37. Schaefer, C.W.; Miles, J. Inhibition by acetylcholine of cockroach heart (Gromphadorhina portentosa). Comp. Gen. Pharmacol. 1970, 1, 426-430. [CrossRef]

38. Carrazoni, T.; de Avila Heberle, M.; Perin, A.P.A.; Zanatta, A.P.; Rodrigues, P.V.; dos Santos, F.D.M.; de Almeida, C.G.M.; Vaz Breda, R.; dos Santos, D.S.; Pinto, P.M.; et al. Central and peripheral neurotoxicity induced by the Jack Bean Urease (JBU) in Nauphoeta cinerea cockroaches. Toxicology 2016, 368-369, 162-171. [CrossRef] [PubMed]

39. Libersat, F.; Pflueger, H.-J. Monoamines and the Orchestration of Behavior. Bioscience 2004, 54, 17-25. [CrossRef]

40. Gal, R.; Libersat, F. A wasp manipulates neuronal activity in the sub-esophageal ganglion to decrease the drive for walking in its cockroach prey. PLoS ONE 2010, 5, e10019. [CrossRef] [PubMed] 
41. Weisel-Eichler, A.; Haspel, G.; Libersat, F. Venom of a parasitoid wasp induces prolonged grooming in the cockroach. J. Exp. Biol. 1999, 202, 957-964. [PubMed]

42. Osborne, R.H. Insect neurotransmission: Neurotransmitters and their receptors. Pharmacol. Ther. 1996, 69, 117-142. [CrossRef]

43. CARR, C.E.; FOURTNER, C.R. Pharmacological analysis of a monosynaptic reflex in the cockroach, Periplaneta americana. J. Exp. Biol. 1980, 86, 259-273.

44. Evans, P.D. Biogenic amines in the insect nervous system. In Advances in Insect Physiology; Elsevier: Amsterdam, The Netherlands, 1980; Volume 15, pp. 317-473. ISBN 0065-2806.

45. Orchard, I. Octopamine in insects: Neurotransmitter, neurohormone, and neuromodulator. Can. J. Zool. 1982, 60, 659-669. [CrossRef]

46. Orchard, I.; Lange, A.B. Evidence for octopaminergic modulation of an insect visceral muscle. J. Neurobiol. 1985, 16, 171-181. [CrossRef]

47. O'Shea, M.; Evans, P.D. Potentiation of neuromuscular transmission by an octopaminergic neurone in the locust. J. Exp. Biol. 1979, 79, 169-190.

48. Theophilidis, G.; Burns, M.D. The innervation of the mesothoracic flexor tibiae muscle of the locust. J. Exp. Biol. 1983, 105, 373-388.

49. Guixà-González, R.; Albasanz, J.L.; Rodriguez-Espigares, I.; Pastor, M.; Sanz, F.; Martí-Solano, M.; Manna, M.; Martinez-Seara, H.; Hildebrand, P.W.; Martín, M. Membrane cholesterol access into a G-protein-coupled receptor. Nat. Commun. 2017, 8, 14505. [CrossRef] [PubMed]

50. Stu, G.D.; de Freitas, T.C.; de Avila Heberle, M.; de Assis, D.R.; Vinadé, L.; Pereira, A.B.; Franco, J.L.; Dal Belo, C.A. Modulation of dopaminergic neurotransmission induced by sublethal doses of the organophosphate trichlorfon in cockroaches. Ecotoxicol. Environ. Saf. 2014, 109, 56-62.

51. Kagabu, S.; Murase, Y.; Imai, R.; Ito, N.; Nishimura, K. Effect of substituents at the 5-position of the pyridine ring of imidacloprid on insecticidal activity against Periplaneta americana. Pest Manag. Sci. Former. Pestic. Sci. 2007, 63, 75-83. [CrossRef] [PubMed]

52. Bradford, M.M. A Rapid and Sensitive Method for the Quantitation of Microgram Quantities of Protein Utilizing the Principle of Protein-Dye Binding. Anal. Biochem. 1976, 72, 248-254. [CrossRef]

53. Full, R.J.; Stokes, D.R.; Ahn, A.N.; Josephson, R.K. Energy absorption during running by leg muscles in a cockroach. J. Exp. Biol. 1998, 201, 997-1012.

54. Giner, J.-L.; Zhao, H.; Beach, D.H.; Parish, E.J.; Jayasimhulu, K.; Kaneshiro, E.S. Comprehensive and definitive structural identities of Pneumocystis carinii sterols. J. Lipid Res. 2002, 43, 1114-1124. [CrossRef] 